\title{
The Dilemma Economic Growth And Poverty Rate In Sulawesi
}

\author{
Kalzum R. Jumiyanti ${ }^{1^{*}}$, Moh. Jamal Moodoeto ${ }^{2}$, Deby Rita Karundeng ${ }^{3}$ \\ 1,2,3 Universitas Gorontalo
}

\section{Article Information}

History of article:

Received August 2020

Approved February 2021

Published March

2021

\begin{abstract}
A B S T R A C T
Economic growth is often cited as a significantly contributive factor reduction of the poverty rate. This study aims to investigate the economic growth and poverty among all areas within Sulawesi Island and to compare these two aspects among the island's provinces. This study employs both comparative quantitative analysis to explore economic grow th formulatively and qualitative manner for in depth analysis. The result reveals an escalation in both gross regional domestic product (henceforth regional GDP) and total population each year for the last ten years. However this situation is unable to boost the macro-economic growth; a reason for this condition is the population growth in the recent ten years possibly dominated by High birth rates. Yet, this condition does not lead to a drop in the demand for workforces, which implies that the number of the working-age population (which can help improve the regional per capita income) remains constant despite the population growth. Another possible factor of regional GDP escalation is the fact that the government policy, in its foreign cooperation implementation, does not contribute to the local workforces. Nevertheless, the rise in regional GDP is insignificant as it does not affect the local economic conditions. Hence, it proves that the fluctuation of economic growth does not affect the poverty rate.
\end{abstract}

Keywords: Economic Growth, Poverty Rate.

JEL Classification Code: O4, O18, I32

(C) 2021 MediaTrend

Author correspondence:

E-mail: yanti.kalzum@gmail.com

DOI: https://doi.org/10.21107/mediatrend.v16i1.8122

(c) 2021 MediaTrend. All rights reserved. 


\section{INTRODUCTION}

Poverty is among the mostcommon issue and the major concern of the government of all countries. In almost every developing country, the majority of its people has considerably low living standard to be compared with not only those in rich countries, but also the elites. One of the low living standard manifestations is the noticeably low income of its people, or in other words, poverty (Todaro as cited in Jayadi, 2016). This explains why poverty is considered a very serious problem in social aspect. Such notion is in line with Usman (2008) who explains the urgency to discuss the problem by determining the concept of poverty and exploring its benchmark, different concepts may lead to different benchmarks, followed by identifying dominant cultural and structural factors that causes poverty.

Purnama (2010) proposes ideas similar to Jayadi and Usman that poverty is among the main concerns in economic development. In its principle, economic development is intended to boost the welfare of society, increase income and promote economic growth in all development sectors, conceptualize optimum equitable development, expand labor and improve public live standard. Accelerated economic growth and equitable distribution of income are essential in attaining the overall development goals.

The government of Indonesia is aware of the national development plan's function among many efforts in achieving a just and prosperous society. On that ground, the government has directed several programs towards regional development specifically in areas that suffer from poverty every year. Regional development programs are integrated and continuous in nature, based on every priority and necessity of each region. Furthermore, the targets of the development programs have been determined in the long-term, mid-term, and annual national development goals. This notion implies that poverty decline is among the contributing factors of the national development success. Effectiveness in reducing the poverty rate is the main consideration in implementing a development strategy. Therefore, the effectiveness of poverty rate decline has been regarded as the key factor in deciding the focus or priority sector of the national development goals (Ravi, as cited in Purnama, 2010).

Economic growth is considered as a factor that significantly contributes in reducing the poverty rate. Talmera (2016), however, proposes different opinions regarding the theories of economic growth: the drawbacks of such theories are mostly the absence of a thorough discussion of the correlation between economic growth and income distribution. The theories rather imply that income inequality is getting worse if economic growth is increasing. It is because the accumulation of the income of the individual and private sector is basically crucial in raising capital for furthering the investment and economic growth that is in line with Harrod-Domar's theory of economic growth. According to the theory, saving and investment play a major role in maximizing economic growth. The problem is that not everyone can save their income. Allocating a budget for saving and investment is the privilege of the rich, while the poor save nothing as they spend their money on fulfilling their needs. Another factor widening the gap of income inequality is the fact that the poor have no access to get loans from a bank or credits to improve their welfare and quality of human resources. This situation in turn causes the unemployment rate and dependency burden continues to soar; to worsen things, such condition also wanes the national income.

The issues of income inequality had occurred in some provinces in 
Indonesia. A study by Soleh (2011) has identified that there is no guarantee that a high economic growth will lead to prosperous society, despite the fact that high economic growth is expected improve public welfare; a concrete example of this problem occurred in Papua Barat: a province with the highest economic growth (11.27\% annually) among other provinces in Indonesia, yet its people live under poverty line, making the province the second poorest area $(35.77 \%)$ right after Papua. The phenomenon depicts the fact that economic growth alone will not help the poor. Western parts of Indonesia has a relatively better economic condition, including the economic growth and poverty rate, compared to its eastern counterpart. In western Indonesia, economic growth is $5.45 \%$ per year, which is higher than the average national economic growth. The percentage of the poor population is $43 \%$, while the population of poor in eastern Indonesia is $57 \%$. In general, some areas in the eastern part of Indonesia are mostly underdeveloped.
In consideration of the disparity between developed and underdeveloped provinces, economic growth functions as a benchmark to measure and cut poverty. This present study relied on the 2013-2017 time-series data by Statistics Indonesia (henceforth referred to as BPS). The objective of this study is to investigate the economic growth and poverty among all areas within Sulawesi Island and to compare these two aspects among the provinces on Sulawesi.

\section{METHODOLOGY}

The objective of this study is to investigate the economic growth and poverty among all areas within Sulawesi Island and to compare these two aspects in the provinces of Sulawesi. Focusing on secondary data, this research relied on online data from the website of Statistics Indonesia (BPS) such as data rate of poverty, while economic growth data acquisition from data PDRB. This study employs both comparative quantitative analysis to explore economic growth formulatively and qualitative manner for in depth analysis.

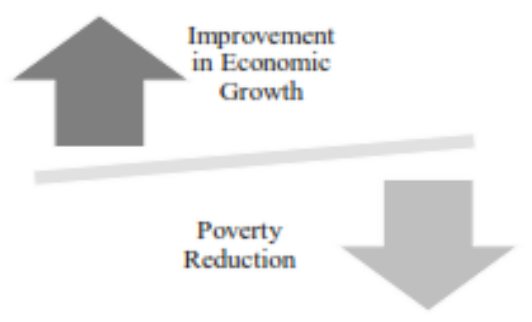

Figure 1

Analysis Framework

Sukirno (as cited in Purnama, 2010) defines the term economic growth as improvement of economic activities that leads to the in crease of goods and services amount produced by people over time. The level of economic growth in a year (year-t) can be determined using the following formula:

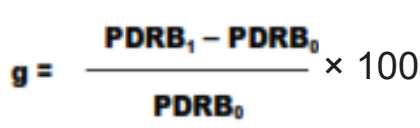

Where $\mathrm{g}$ is level (percentage) of economic growth, $\mathrm{PDRB}_{1}$ is income of regional GDP in the current year, and $\mathrm{PDRB}_{0}$ is income of regional GDP in the previous year. 


\section{RESULTS AND DISCUSSION}

The economic conditions in Sulawesi Island, similar to other provinces in Indonesia, head toward positive growth; this is seen in the improvement of macroeconomic conditions of the areas within the island. Potential and non-potential economic sectors of every province in Sulawesi also take part in enhancing the economic condition. In general, the potential economic sectors are the dominant businesses or sectors that absorb employers more. This sector can also be regarded as the high-growth sector that contributes to the domestic product, which represents the distinctive economy characteristics of an area. Provided in the following Table 1 is the regional GDP's current price depicting the economic conditionsof all provinces in Sulawesi from 2013 to 2017.

Table 1

Regional GDP's Current Price of Business Sectors (Billion Rupiah) in Sulawesi, 2013-2017

\begin{tabular}{lrrrrr}
\hline Province & 2013 & \multicolumn{1}{c}{2014} & \multicolumn{1}{c}{2015} & \multicolumn{1}{c}{2016} & \multicolumn{1}{c}{2017} \\
\hline North Sulawesi & $71,097.46$ & $80,667.63$ & $91,145.68$ & $100,542.57$ & $110,164.48$ \\
Gorontalo & $22,129.28$ & $25,193.78$ & $28,493.42$ & $31,702.12$ & $34,547.56$ \\
Central Sulawesi & $79,842.22$ & $90,246.27$ & $107,573.47$ & $120,204.03$ & $134,243.41$ \\
West Sulawesi & $25,249.49$ & $29,458.25$ & $32,987.55$ & $35,958.50$ & $39,617.97$ \\
Southeast & $71,041.25$ & $78,622.15$ & $87,714.48$ & $97,011.99$ & $107,465.20$ \\
Sulawesi & & & & & \\
South Sulawesi & $258,836.42$ & $298,033.80$ & $340,390.21$ & $379,632.26$ & $418,931.58$ \\
\hline
\end{tabular}

Source: Statistics Indonesia, GDP among the Provinces within Sulawesi Island

The above regional GDP data are based on the production approach, in which the total value per year is the accumulation of the total of the added value of goods and services made (or produced) by every production unit within every province in Sulawesi Island. According to Table 1, provinces with the highest regional GDP are South Sulawesi, Central Sulawesi, and North Sulawesi. The regional GDP growth of South Sulawesi from 2013 to 2017 is $7.62(2013) ; 7.54$ (2014) ; 7.19 (2015) ; 7.42 (2016) ; 7.23 (2017) (Central Agency on Statistics, South Sulawesi, 2018). The data, however, do not represent a positive growth rate in Sulawesi. Central Sulawesi is the province that has shown the most sustained and robust regional GDP among other provinces in Sulawesi. The growth rate of regional GDP of Central Sulawesi is 14.65 (2013) ; 13.03 (2014) ; 19.20 (2015) ; 11.74 (2016) ;11.68 (2017) (Central Agencyon Statistics, South Sulawesi, 2018).
The data above are a depiction of the economic condition of Sulawesi based on its regional GDP. Regional GDP is, in general, the total of the added value of goods and services made (or produced) by every economic activity within an area in a certain period (Regional Development and Planning Board of Pakpak Bharat Regency - Division of Economy, 2013). There are three ways to calculate regional GDP; those are production method, income method, and expenditure method.

According to the data of the population census in 2000, Sulawesi's population density was 14,946,488 residents. The distribution of the population was 2,012,098 (NorthSulawesi), 2,218,435 (Central Sulawesi), 8,059,627 (South Sulawesi), 1,821,284 (Southeast Sulawesi), and 835,044 (Gorontalo) (Statistics Indonesia, 2014). Compared to the population census in 2010, the population in Sulawesi had grown to $17,371,782$, indicating an increase in the 
number of residents by 2,425 million. According to the projection of population growth, it is estimated that the human population in Sulawesi will keep growing, growth in Sulawesi.

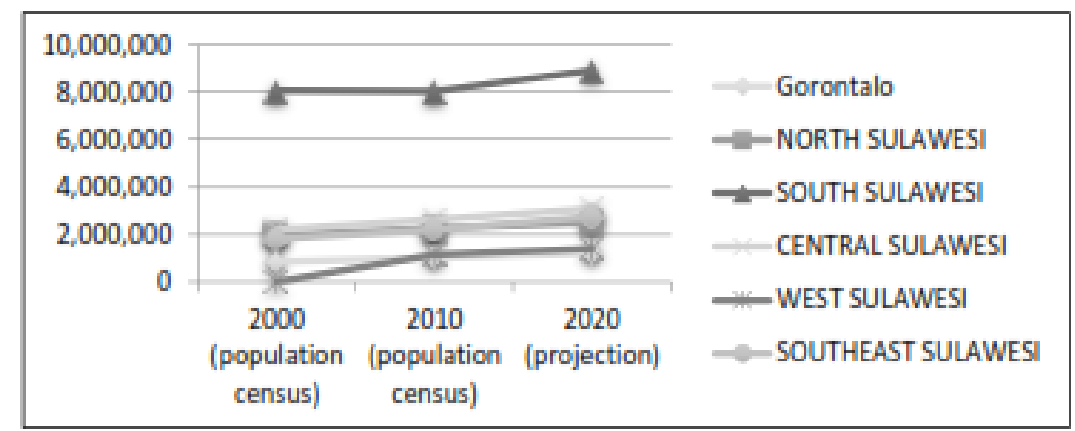

Source: Statistics Indonesia 2000-2020

\section{Figure 2}

\section{Population Growth in Sulawesi Island}

As a developing country, Indonesia deals with issues regarding economic growth crisis and poverty, which leads to income inequality. Inspired by the theory of analysis by Karl Marx and Frederick Engels, the founder of the social-democracy theory, Nawawi (2009) opines that poverty is rather a structural problem, not an individual problem. Poverty is a result of injustice and discrepancy in society that prevents people from accessing resources or everything they need to enhance their life. The wider the gap between the high-social class and low-social class people, the more the number of poor.

Income inequality and indigence, however, are not two different discourses despite the interrelation between these aspects. This notion reflects the argument by Sen (as cited in Wie, 1981) that income transfer of those in middle-class to upper-class worsens the level of inequality, but the situation does not affect those in the lower-class. The following table provides information about the percentage of poor in Sulawesi.

Table 2

Percentage of Poor Population in 2012-2017

\begin{tabular}{|c|c|c|c|c|c|c|}
\hline Province & 2012 & 2013 & 2014 & 2015 & 2016 & 2017 \\
\hline $\begin{array}{l}\text { North } \\
\text { Sulawesi }\end{array}$ & 7.91 & 8.19 & 8.51 & 8.81 & 8.27 & 8 \\
\hline $\begin{array}{l}\text { Central } \\
\text { Sulawesi }\end{array}$ & 15.17 & 14.49 & 13.77 & 14.36 & 14.27 & 14.18 \\
\hline $\begin{array}{l}\text { South } \\
\text { Sulawesi }\end{array}$ & 9.96 & 9.93 & 9.91 & 9.75 & 9.32 & 9.43 \\
\hline $\begin{array}{l}\text { Southeast } \\
\text { Sulawesi }\end{array}$ & 13.38 & 13.28 & 13.41 & 13.32 & 12.82 & 12.39 \\
\hline Gorontalo & 17.25 & 17.76 & 17.42 & 18.24 & 17.67 & 17.39 \\
\hline $\begin{array}{l}\text { West } \\
\text { Sulawesi }\end{array}$ & 13.12 & 12.26 & 12.16 & 12.15 & 11.46 & 11.24 \\
\hline
\end{tabular}

Source: Processed Data (Statistics Indonesia, 2018)

Table 2 shows that the percentage 2012 to 2017, rather fluctuates. Further, of the poor population in Sulawesi, from the table reveals that Gorontalo is 
the province with the highest percentage Southeast Sulawesi, West Sulawesi, of poor; it is followed by Central Sulawesi, South Sulawesi, and North Sulawesi.

Table 3.

Gini Ratio Indonesia 2007-2018

\begin{tabular}{ccccc}
\hline \multicolumn{5}{c}{ Village + Urban Area } \\
\hline Year & Gini Ratio & Year & Gini Ratio \\
\hline Mar'2007 & 0.376 & $;$ & Mar'2013 & 0.413 \\
\hline Mar'2008 & 0.368 & $;$ & Mar'2014 & 0.406 \\
\hline Mar'2009 & 0.367 & $;$ & Mar'2015 & 0.408 \\
\hline Mar'2010 & 0.378 & $;$ & Mar'2016 & 0.397 \\
\hline Mar'2011 & 0.410 & $;$ & Mar2017 & 0.393 \\
\hline Mar'2012 & 0.410 & $;$ & Mar2018 & 0.389 \\
\hline
\end{tabular}

Sources of Data: (Statistics Indonesia, 2019)

Gini ratio, according to Statistics Indonesia (2017), is one of the benchmarks of the income distribution of people regardless of their social status. A Gini coefficient that is close to zero represents equality in wealth distribution. On the one hand, the ratio that is close to one means inequality.

Indonesia has posted improving the Gini ratio; it stays in 0.40 every year.
Although the Gini ratio of Indonesia was 0.30 back in the 2000s, the ratio significantly increased to 0.37 in early 2010, and it remained constant in 0.41 from 2011 to 2015. The data imply that the upper-class is the one that benefits much from economic growth rather than the lower-class.

The inequality severity index of every province in Sulawesi is provided in the following table.

Table 4

The Percentage of Poverty Severity Index of the Provinces (Urban Areas and Villages)

\begin{tabular}{lccccc}
\hline Province & 2013 & 2014 & 2015 & 2016 & 2017 \\
\hline North Sulawesi & 0.28 & 0.30 & 0.44 & 0.34 & 0.30 \\
Gorontalo & 0.85 & 0.83 & 0.88 & 0.65 & 0.85 \\
Central Sulawesi & 0.53 & 0.55 & 0.60 & 0.56 & 0.78 \\
West Sulawesi & 0.27 & 0.51 & 0.31 & 0.44 & 0.45 \\
Southeast & 0.43 & 0.52 & 0.49 & 0.46 & 0.52 \\
Sulawesi & & & & & \\
South Sulawesi & 0.40 & 0.32 & 0.45 & 0.38 & 0.50 \\
\hline
\end{tabular}

Source: 2018

The poverty severity index, in poverty among other provinces; it is well-known as P2, illustrates the represented by the average percentage distribution of expenditure of poor (Statistics Indonesia, 2019). The higher the index, the wider the gap of the inequality of expenditure. According to the above data, Gorontalo is the province that has the highest population living of poverty severity index of $0.80 \%$.

The following table is the percentage of economic growth and poverty rate in Sulawesi; the data were calculated using the formula of economic growth. 
The Dilemma Economic ..... MediaTrend 16 (1) 2021 p. 40-48

Table 5

Percentage of Economic Growth in Sulawesi and Percentage of Poor

\begin{tabular}{crrrc}
\hline & \multicolumn{5}{c}{ Economic Growth/year } \\
\cline { 2 - 5 } Province & 2014 & 2015 & 2016 & 2017 \\
\hline Gorontalo & 13.85 & 13.10 & 11.26 & 8.97 \\
\% of poor & 17.42 & 18.24 & 17.67 & 17.39 \\
\hline Central Sulawesi & 13.03 & 19.20 & 11.74 & 11.68 \\
$\%$ of poor & 13.77 & 14.36 & 14.27 & 14.18 \\
\hline Southeast Sulawesi & 10.67 & 11.56 & 10.60 & 10.78 \\
$\%$ of poor & 13.41 & 13.32 & 12.82 & 12.39 \\
\hline West Sulawesi & 16.67 & 11.98 & 9.01 & 10.18 \\
\% of poor & 12.16 & 12.15 & 11.46 & 11.24 \\
\hline South Sulawesi & 15.14 & 14.21 & 11.53 & 10.35 \\
$\%$ of poor & 9.91 & 9.75 & 9.32 & 9.43 \\
\hline North Sulawesi & 13.46 & 12.99 & 10.31 & 9.57 \\
$\%$ of poor & 8.51 & 8.81 & 8.27 & 8 \\
\hline
\end{tabular}

Source: Processed Data (2019)

Table 5 shows a decline in the economic growth of all provinces in Sulawesi from 2014 to 2017. Economic growth caused by increased REGIONAL GDP is found to be insignificant on the improvement of the level of economic strata of society. On the other hand, the percentage of poor population fluctuates every year, meaning that advancement in economic growth does not affect the decline and rise in the percentage of poor.

The condition in North Sulawesi is a concrete example of the issue previously mentioned. It shows that the regional GDP and population growth in the province are growing in the last ten years. This situation, however, is unable to boost the macro-economic growth; a reason for this condition is the population growth in the recent ten years. High birth rates possibly dominate the increase in the number of the population. Yet, this condition does not lead to a drop in the demand for workforces. This implies that the number of the working-age population (which can help improve the regional per capita income) remains constant despite the population growth. Another factor causing the increase in regional GDP is the fact that the government policy, in its foreign cooperation implementation, does not contribute to the local workforces. Nevertheless, the rise in regional GDP is insignificant as it does not affect the local economic conditions.

Sukirno (as cited in Purnama, 2010) claims that the quantity and quality of population and workforce are central to advance the economic growth of a region. Although the population continues to grow, poverty issues remain unsolved if there are no attempts to boost the quality of the human workforce and increasing the job opportunity. The idea by Sadono Sukirno, however, does not ensure that a rise or decline in the economic growth will be significant to the poverty rate since the theory demands in-depth analysis.

The discussion above represents the overall condition of economic growth in all provinces in Sulawesi, including Central Sulawesi, West Sulawesi, and Southeast Sulawesi. Gorontalo is the province with the worst poverty severity index, which stuck at $0.80 \%$ on average every year (see Table 4). In addition to the number of the population, the issue of indigence in the province is determined by the lack of capital goods and technology exposures. The social system and attitude of the people in Gorontalo that highly value its local 
wisdom are often cited as the factor contributing to the number of unfortunate in the province.

Improvement in economic growth is supposed to bring a positive change to a region. Factors, such as a rise in regional GDP sectors, is also inevitable to elevate economic growth comprehensively. These sectors are expected to create more job opportunities, which in turn, can raise the consumption of people (this idea syncs to the poverty crisis). Ignoring poverty or no changes (even a decline) in economic growth does not lead to a break in the cycle of poverty. In conclusion, success in raising or sustaining the percentage of economic growth depends on land and other natural resources, quantity and quality of a population and human capital, capital goods and technology, as well as a social system and attitude of society.

\section{CONCLUSIONS}

The percentage of the economic growth in Gorontalo was $13.85 \%$ back in 2014. However, the percentage dropped by $13.10 \%$ in the next year. In 2016 and 2017, the economic growth of the province declined to $11.26 \%$ and $8.97 \%$, respectively. Gorontalo is the province with the most people living below the poverty line among other provinces in Sulawesi (average percentage of $17.51 \%$ ). Back in 2014, the percentage of the economic growth in Central Sulawesi was 13.03 percent, and it increased by $19.20 \%$ in 2015. A drop in economic growth was inevitable in 2016 (decreased by $11.74 \%$ ) and in 2017 (decreased by 11.68\%). Central Sulawesi is the second-highest province with people living below the poverty line compared to other provinces in Sulawesi (average percentage of $14.32 \%$ ).

Economic activity in Southeast Sulawesi tends to fluctuate over the years. The rise in economic growth in 2014 and 2015 was $10.67 \%$ and $11.56 \%$, respectively. However, the improvement was insignificant. Later in 2016, the condition of economics in Central Sulawesi fell by $10.60 \%$, yet it increased by 10.78 percent in 2017. The average percentage of poor in this province is $12.89 \%$. In West Sulawesi, the economic growth in 2014 was $16.67 \%$. The percentage of economic growth in the province dropped by $11.98 \%$ and $9.01 \%$ in 2015 and 2016, respectively. The percentage, however, increased by $10.18 \%$ during the next year, although it was not that significant. The population of poor in this province reaches $10.48 \%$. In 2014, the condition of the economic growth of South Sulawesi was $15.14 \%$. The percentage of the economic growth in North Sulawesi was $13.46 \%$ in 2014 , and it later decreased by $12.99 \%$ in the following year. A decline in the percentage of economic growth still occurred in 2016 (10.31\%) and 2017 (9.57\%).

\section{REFERENCE}

Badan Pusat Statistik. (2014). Badan Pusat Statistik- Jumlah Penduduk Provinsi. Retrieved from https:// www.bps.go.id/statictable /2014/02/18/1274/proyeksi -penduduk-menurut-provinsi -2010---2035.html

Badan Pusat Statistik. (2017). Laju Pertumbuhan Penduduk menurut Provinsi. Retrieved from https:// www.bps.go.id/statictable / 2009 / 02 / 20 / 1268 / Iaju pertumbuhan-penduduk-menurut -provinsi.html

Badan Pusat Statistik. (2018). Badan Pusat Statistik. Retrieved from h t t p s: / / w w w. b ps.go.id / linkTableDinamis/view/id/1116

Badan Pusat Statistik Provinsi Sulawesi Selatan. (2018). Produk Domestik Regional Bruto Provinsi Sulawesi Selatan Menurut Lapangan Usaha 2013-2017. (Badan Pusat Statistik Provinsi Sulawesi Selatan, Ed.). 
Sulawesi Selatan: Badan Pusat Statistik Provinsi Sulawesi Selatan. Bappeda Kabupaten Pakpak Barat - Bidang Perekonomian. (2013). Pengertian PDRB dan cara perhitungannya. Retrieved from https://economic bappedapakpak.wordpress.com / 2013 / 02 / 21 / pengertian pdrb-dan-cara-perhitungannya/

BPS. (2019). Badan Pusat StatistikKemiskinan dan Ketimpangan. Retrieved from https://www.bps. go.id/subject/23/kemiskinan-danketimpangan.htmI\#subjekView Tab1

BPS Nasional. (2019). Badan Pusat Statistik_Kemiskinan dan Ketimpangan.Retrievedfromhttps:// www.bps.go.id/subject/23/ kemiskinan-dan-ketimpangan.html

Divisi Statistik Data Sekunder. (2015). Produk Domestik Regional Bruto (PDRB). Jakarta: Departemen Statistik. Retrieved from https:/ www.bi.go.id/id/.../Produk Domestik Regional Bruto (PDRB)_rev160615.pdrb

Jayadi, D. S. (2016). Peran Pertumbuhan Ekonomi Dalam Menurunkan Kemiskinan di tingkat Provinsi di Indonesia Tahun 2004-2012. Modus, 28(1), 87-99.

Nawawi, Ismail, 2009. Pembangunan dan Problema Masyarakat: Kajian Konsep, Model, Teori dari Aspek Ekonomi dan Sosiologi. Putra Media Nusantra, Surabaya.

Purnama, N. I. (2010). Analisis Pengaruh Pertumbuhan Ekonomi Terhadap Tingkat Kemiskinan Di Sumatera Utara. Sumatera Utara.

Siregar, H., \& Wahyuniarti, D. (2006). Dampak Pertumbuhan Ekonomi Terhadap Penurunan Jumlah Penduduk Miskin - Impact of Economic Growth on The Reduction of Poor People. Direktur Kajian Ekonomi: Institusi
Pertanian Bogor, 1-18.

Soleh, A. (2011). Pertumbuhan Ekonomi dan Kemiskinan Di Indonesia. Ekombis Review, 197-209.

Talmera, D. A. (2016). Pertumbuhan Ekonomi, Ketimpangan Pendapatan, dan Kemiskinan di Indonesia. Indonesia. Retrieved from https://www.academia.edu/ 34139209 / Pertumbuhan Ekonomi_Ketimpangan_ Pendapatan_dan_kemiskinan

Usman, D. S. (2008). Pembangunan dan Pemberdayaan Masyarakat (Ke-5). Yogyakarta: Pustaka Pelajar.

Wahyudi, D., \& Rejekingsih, T. W. (2013). AnalisisKemiskinanDiJawaTengah. Diponegoro Journal Of Economics, 2, 1-15. Retrieved from https:// ejournal3.undip.ac.id/index. php/jme/article/view/1914/1912

Wie, Thee Kian, 1981. Pemerataan Kemiskinan Ketimpangan: Beberapa Pemikiran tentang Pertumbuhan Ekonomi. Sinar Harapan. Jakarta. 